\title{
Stem-base disease in winter durum and common wheat cultivation in the years 2009-2011
}

\author{
Dorota Gala ${ }^{1}$ Anna Gorczyca²*, Andrzej Oleksy33, Marek Kołodziejczyk \\ ${ }^{1}$ Department of Agrotechnology and Agricultural Ecology, \\ ${ }^{2}$ Department of Agricultural Environment Protection, \\ ${ }^{3}$ Department of Crop Production, \\ University of Agriculture in Kraków, Al. Mickiewicza 21, 31-120 Kraków, Poland
}

Received: June 18, 2013

Accepted: January 14, 2014

\begin{abstract}
The occurrence of stem-base diseases in two cultivars of winter wheat were evaluated in a 3-year experiment, using two agrotechnology levels. The two cultivars evaluated were durum wheat of the Komnata cultivar and common wheat of the Ostka Strzelecka cultivar. The highest intensity was noted in the occurrence of two diseases of the complex, i.e. Fusarium foot rot and eyespot. The examined cultivars were characterized by a similar susceptibility to these diseases. There was an observed difference - a slightly higher susceptibility by the Komnata as opposed to the Ostka Strzelecka cultivar - but it was not significant statistically. Significant differentiation in infestation was noted for other experimental factors like cultivation season and the agrotechnology level. Intensification of the occurrence of both stem-base diseases in the experimental seasons did not affect the mean amount and quality of the yield obtained in the experiment.
\end{abstract}

Key words: common wheat, durum wheat, stem-base diseases, weight of 1,000 grains, yield

\section{Introduction}

Currently, the worldwide production of durum wheat considerably exceeds $35 \mathrm{Mt} /$ year. Production in the European Union is focused mainly in the Mediterranean region and constitutes as much as $26 \%$ of world production. The yield obtained in European countries is significant, as $14 \%$ of the global area of this species under cultivation, amounting to 18 million ha, is localized in EU countries (Anonymous 2009; Blandino et al. 2009; Rachoń and Szumiło 2009). The price of durum wheat grain is higher than the more popularly cultivated common wheat. This is mainly due to the method of durum grain utilization. This grain constitutes the best raw material for production of the pasta consumed all over the world. Durum wheat grain is characterized by higher levels of protein, gluten, and carotenoids. It has a higher glassiness and endosperm hardness than common wheat grain (Rachon et al. 2002; Rachoń 2004; Katerji et al. 2005; Rachoń and Szumiło 2006; Ficco et al. 2009; Budzyński 2012).

Durum wheat is a typical plant of continental climates. Abundant precipitation during the period of intensive plant growth, and the dry, hot summers favor formation of a hard, glossy grain having a high protein content (Blandino et al. 2009). Due to the increased popularity of durum products (pasta, couscous, bulgur, desserts) interest in durum wheat cultivation has increased in those regions where this valuable cereal had not been cultivated previously, e.g. in Germany, Austria, Hungary as well as Poland (Ficco et al. 2009; Rachoń and Szumiło 2009; Budzyński 2012).

Cereal diseases, including stem-base diseases, to a high degree determine the amount and quality of yield obtained. The stem-base disease complex includes seedling diseases, i.e. pink snow mold, gray mold, seedling blight as well as diseases of the roots and stem base-eyespot, root and stem-base disease, Fusarium foot rot, common root rot, and sharp eyespot. Economically, the most significant stem-base diseases in winter cereal cultivation in Poland are Fusarium foot rot and eyespot (Korbas et al. 2008; Korbas and Mrówczyński 2009).

Cereal fusariosis (roots, stem base, stalks, leaves, and ears) are caused by fungi of the Fusarium genus. Most often, the causes of these diseases are $F$. graminearum, $F$. culmorum, and F. avenaceum species. The mentioned species may occur in the form of a complex. They are noted in various levels in different geographical regions (Menniti et al. 2003; Wagacha and Muthomi 2007; Chekali et al. 2011; Suproniene et al. 2011). Symptoms of one of these diseases, i.e. Fusarium foot rot, may be observed not only on the stems, but also on the roots of wheat. On the stems, this disease shows up as brown patches, which often have a violet shade and take various shapes. Also, browning of the elbows is characteristic for this fusariosis. Infestation of the roots is noted by the color change to dark-brown (Korbas and Mrówczyński 2009; Budzyński 2012). Apart from a yield decrease, the essential harmfulness of $\mathrm{Fu}$ - 
sarium ssp. fungi involves the production of mycotoxins - secondary metabolites harmful to human and animal health (Perkowski et al. 1997; Champeil et al. 2004; Vujanovic et al. 2012). Eyespot is a result of infestation by fungi of the Oculimacula genus. Eyespot symptoms include oblong, lenticular shadows of a light or dark-yellow color visible on the stems and surrounded by a brown border. At the site of infestation, the stem becomes fragile, less stable and more susceptible to being beaten-down. With a strong infestation, the whole stem base is subject to rotting (Korbas and Mrówczyński 2009; Budzyński 2012).

Fungi of the Fusarium genus are the highest danger for yields in the cultivation of common and durum wheat (Champeil et al. 2004; Edwards 2004; Fernandez and Chen 2005; Yoshida and Nakajima 2008). The fungi has been noted in all the development phases of the durum wheat; starting from germination to full maturity. Fusarium ssp. inhabit not only the morphological structures of wheat (roots, stems, leaves, ears, and even ear awns) but also the soil. The grain of infested plants is contaminated with mutagenic and carcinogenic mycotoxins. The Fusarium genus has demonstrated considerable quantitative domination over other pathogenic fungi (inter alia Cladosporium, Epicoccum, Ceratobasidium genus), which are observed in wheat cultivation (Vujanovic et al. 2012). The first fusariosis which occurs both on common and durum wheat is Fusarium foot rot. It is important to recognize the factors stimulating and inhibiting infection, in order to prevent further infestation of the plants (Fernandez and Chen 2005). There has been an increased interest in durum wheat because it has better grain quality (inter alia higher protein content). Grain infestation by Fusarium ssp. and, as a consequence its contamination with mycotoxins, is an unacceptable phenomenon.

A large number of reports concerning ear fusariosis observed on common and durum wheat, may be found in the literature. Numerous studies also determine the influence of mycotoxins on yield quality. Yet, there is little information concerning stem-base diseases observed on wheat, especially on durum wheat. The susceptibility of common wheat to stem-base diseases is quite well recognized in Poland. However, the susceptibility of durum wheat, a cereal new in Poland's climatic conditions, has not yet been examined sufficiently.

Studies aimed at an assessment of durum wheat cultivation in regions with less favorable climatic conditions are, thus, justified. The aim of this study was to compare the occurrence and harmfulness of stem-base diseases in the cultivation of durum wheat of the Komnata cultivar and common wheat of the Ostka Strzelecka cultivar, in the 2009-2011 seasons, in climatic-soil conditions of a selected region of Małopolska, Poland.

\section{Materials and Methods}

\section{Agronomic conditions}

The experiment was conducted on experimental plant land in the village of Prusy (50 $\left.06^{\prime} 52^{\prime \prime} \mathrm{N} ; 20^{\circ} 04^{\prime} 23^{\prime \prime} \mathrm{E}\right)$. The land belongs to the Department of Detailed Plant Cultivation, University of Agriculture in Kraków, Poland. The following experimental factors were applied over the three years of the field experiment (vegetation seasons: 2008/2009, 2009/2010, 2010/11):

- two cultivars of winter wheat: Komnata - a cultivar of durum wheat, Ostka Strzelecka - a cultivar of common wheat;

- two agrotechnology levels: moderately-intensive - A1, without fungicidal protection, with lower nitrogen fertilization, and intensive - A2, included two sprayings with fungicide and higher nitrogen doses.

The experiment was established using the random block method in four repetitions. The wheat was cultivated on degraded chernozem, classified as 1st class in terms of both soil quality and agricultural potential. The experiment was conducted on slightly acidic soil; the $\mathrm{pH}$ in 1-molar $\mathrm{KCl}$ was 6.3. The levels of phosphorus and magnesium in the soil were determined as high, while the potassium level was low. The forecrop for wheat in the first experimental season was horse bean, while it was potato in the second and third ones. Soil cultivation was performed according to proper agrotechnology rules. Ploughing at a depth of $20-25 \mathrm{~cm}$ was conducted in the second quarter of September, and harrowing after that. Prior to the treatments, the soil was prepared for sowing, and phosphorus and potassium fertilization was applied in the same amounts for both agrotechnology levels $-80 \mathrm{~kg}$ $\mathrm{P}_{2} \mathrm{O}_{5} /$ ha and $150 \mathrm{~kg} \mathrm{~K}{ }_{2} \mathrm{O} / \mathrm{ha}$. Then, in order to mix the fertilizers with the soil and also to prepare the upper layer for sowing, a cultivation-sowing apparatus composed of a cultivator with narrow arms and a double string shaft, was employed. Before sowing, the grain was treated with Funaben T 480 FS seed treatment (a.i.: thiuram, carbendazim). The sowing was performed at the end of September or at the beginning of October (30.09-6.10) - depending on the season of the study. The evaluated wheat cultivars were sowed at a depth of $2-3 \mathrm{~cm}$, with a row spacing of $12.5 \mathrm{~cm}$, in the amount of $450 \mathrm{pcs} / \mathrm{m}$. The first nitrogen dose was applied to the plants after the onset of vegetation - i.e. in the tillering phase. In the moderate-intensive technology A1, $70 \mathrm{~kg} \mathrm{~N} / \mathrm{ha}$ was used. In the intensive technology A2, $80 \mathrm{~kg} \mathrm{~N} / \mathrm{ha}$ was used. The second nitrogen dose was the same dose for both levels; amounting to $50 \mathrm{~kg} \mathrm{~N} / \mathrm{ha}$. This second dose was applied in the shooting phase. The third nitrogen dose - $30 \mathrm{~kg} \mathrm{~N} / \mathrm{ha}$ - was applied only to those plants cultivated in the intensive technology A2. Weeds were chemically treated in the tillering phase. Monocotyledons were destroyed with Puma Universal 069 EW herbicide (a.i.: fenoxaprop-P-ethyl) at a dosage of $1.2 \mathrm{l} / \mathrm{ha}$, while dicotyledons were treated with Lintur 70 WG agent (a.i.: dicamba, triasulfuron) at a dosage of $160 \mathrm{~g} / \mathrm{ha}$. Fungicidal protection, which concerned only the wheat cultivated in the intensive agrotechnology level, included two treatments. The first spraying, against pathogens causing stem-base diseases, was performed in the shooting phase (BBCH 30), using Tilt Plus 400 EC fungicide (a.i.: propiconazole, fenpropidine) at a dosage of 1 1/ha. The second treatment, aimed to prevent leaf and ear infections, and was performed at the beginning of the tillering phase (BBCH 51) using Artea 330 EC fungicide (a.i.: propiconazole, cyproconazole) at a dosage of $0.5 \mathrm{l} / \mathrm{ha}$. 
Foliar fertilization with microelements was employed at the same time as the application of fungicidal agents. Two fertilizers were used: Basfoliar 36 Extra at a dosage of 9 1/ha in the shooting phase, and YaraVita Cereal at a dosage of $11 /$ ha in the tillering phase.

\section{Weather conditions}

Weather conditions play a significant role in terms of the occurrence and harmfulness of pathogens in plant cultivation. Average air temperatures and the sum of precipitation were of special significance. Considerable variability in humidity-thermal conditions was observed during the three vegetation seasons of the conducted experiments (Fig. 1).

When compared to long-standing values, considerably lower average air temperatures were noted in the $2008 / 2009$ vegetation season and in the period from December to February 2009/2010. A similar situation was observed in the December of the last experimental season. In historical terms, precipitation was considerably more abundant in spring 2009 (May-June), and especially in the spring and summer of 2010 (May-September). The last vegetation season, the wheat health status was examined and appeared to be considerably drier than that typically noted in the region of the study. Among the three experimental seasons, the 2009/2010 season was generally considered the most favorable to the development of pathogens, i.e. characterized by cold and humid weather. The pattern of weather conditions in this period, and especially the abundant rainfall observed in May 2010, could potentially cause higher infestation of wheat by pathogenic fungi.

\section{Analysis of health}

Macroscopic observations of winter durum and common wheat were done to assess the degree of infestation by parasites which cause stem-base diseases. The observations were conducted during the blooming stage of each vegetation season. Ten randomly collected plants from each replication, cultivar and agrotechnology level were evaluated during each analysis. A generally accepted 4-point graphical scale was applied for the assessment of the degree of wheat infestation by the fungi. Infestation degree is determined based on the percentage of pathogenic changes covering the examined plant. Infestation of the first degree signifies complete infection of the stembase by a pathogen. Infestation of the fourth degree signifies a lack of infestation symptoms. The results obtained on the scale were recalculated as a percentage infestation index indicating the purporting of moderately infected plants in a field.

Statistical analysis of health status results was performed using three-factor analysis of variance (vegetation season, cultivar, agrotechnology level). Significance of the data differentiation was verified using the Student's t-test with Bliss transformation at a significance level of $\mathrm{p}=0.05$.

\section{Analysis of yield}

The yield and weight of 1,000 grains (TGW) obtained in the experiment were also subject to evaluation. In this case, the data were also analyzed statistically using a three-factor analysis of variance (vegetation season, cultivar, agrotechnology level). The significance of differences was verified using the Student's t-test.

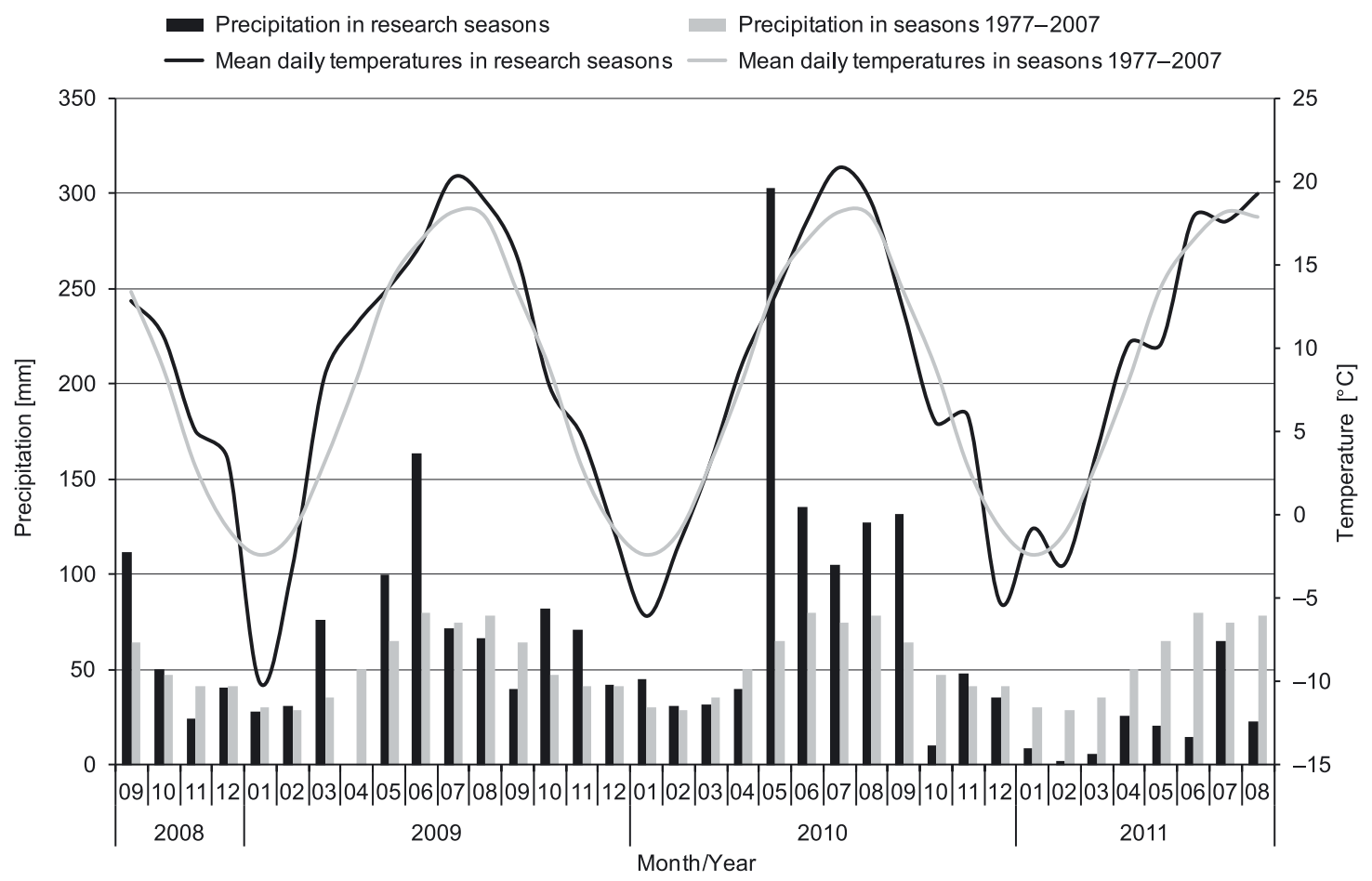

Fig. 1. Weather conditions for the multi-year seasons and research seasons at the Prusy Experimental Station near Kraków 


\section{Results and Discussion}

An intensified occurrence of two wheat stalk-base diseases from the complex of stem-base diseases, was observed during the health status analysis. These were: Fusarium foot rot - caused by fungi of the Fusarium genus, and eyespot - caused by Oculimacula spp. Other diseases of the complex were either not observed or their severity was negligible. In Poland, the economic significance of both diseases noted in the experiment, is estimated as very high (Korbas et al. 2008; Korbas and Mrówczyński 2009; Budzyński 2012).

The obtained values for an index of wheat plant infestation with Fusarium spp. fungi are presented in table 1. The applied agrotechnology level as well as the year of cultivation, determined the intensity of the Fusarium foot rot occurrence. The highest infestation index of three vegetation seasons was noted in the third year of cultivation, i.e. $2010 / 2011(10.48 \%)$. This was a season of relatively low precipitation compared both to other experimental seasons and to historical data. Humidity is not essential for the development of this disease, unlike other stem-base diseases (Korbas and Mrówczyński 2009). Statistically significant limitations in the occurrence of Fusarium foot rot were obtained in the case of the intensive agrotechnology level (infestation index -
$3.02 \%)$, when compared to the moderate-intensive level (infestation index $-11.43 \%$ ). Infestation of the two examined wheat cultivars was not differentiated in a statistically significant manner. The calculated mean index of infestation by Fusarium ssp. in the Komnata cultivar was $6.67 \%$ (a), while for the Ostka Strzelecka cultivar, the value was only slightly lower $-6.52 \%$ (a).

According to Wagacha and Muthomi (2007), fungi of the Fusarium genus infect not only the stem, but also the leaves and ears of the wheat. In turn, Vujanovic et al. (2012) conducted a study on which it may be concluded, that among pathogenic fungi observed on durum wheat in particular stages of development, the highest infestation was caused by Fusarium ssp. The symptoms of their parasitizing were noted in the form of Fusarium foot rot, fusariosis of leaves, and fusariosis of ears. Both Chekali $e t$ al. (2011) and Vujanovic et al. (2012) observed the highest effect of fusariosis of stem-base and fusariosis of flower clusters on yield drop. All the mentioned authors, as well as Champeil et al. (2004), focused on the danger related to mycotoxin production by fungi of the Fusarium genus.

The Oculimacula yallundae and O. acuformis fungi infestation of wheat stem-base observed in this study, being the cause of eyespot, was less differentiated than that noted for Fusarium foot rot. The calculated mean infestation indices are presented in table 2 . The intensity of eyespot

Table 1. Index of wheat infestation by Fusarium ssp. fungi, which is the cause of Fusarium foot rot (\%)

\begin{tabular}{|c|c|c|c|c|}
\hline \multirow{2}{*}{ Vegetation season } & \multirow{2}{*}{ Cultivar } & \multicolumn{2}{|c|}{ Level of agrotechnology } & \multirow{2}{*}{ Seasonal mean } \\
\hline & & A1 (moderate-intensive) & A2 (intensive) & \\
\hline \multirow{2}{*}{$2008 / 2009$} & Komnata & $7.64 \mathrm{~cd}^{*}$ & $0.48 \mathrm{ab}$ & \multirow{2}{*}{$6.25 \mathrm{ab}^{* * *}$} \\
\hline & Ostka Strzelecka & $14.68 \mathrm{~d}$ & $7.02 \mathrm{~cd}$ & \\
\hline \multirow{2}{*}{$2009 / 2010$} & Komnata & $15.03 \mathrm{~d}$ & $5.45 \mathrm{bcd}$ & \multirow{2}{*}{$3.82 \mathrm{a}$} \\
\hline & Ostka Strzelecka & $2.33 \mathrm{abc}$ & $0.00 \mathrm{a}$ & \\
\hline \multirow{2}{*}{$2010 / 2011$} & Komnata & $16.72 \mathrm{~d}$ & $2.64 \mathrm{abc}$ & \multirow{2}{*}{$10.48 \mathrm{~b}$} \\
\hline & Ostka Strzelecka & $16.90 \mathrm{~d}$ & $9.34 \mathrm{~cd}$ & \\
\hline \multicolumn{2}{|c|}{ Mean for level of agrotechnology } & $11.43 b^{* *}$ & $3.02 \mathrm{a}$ & - \\
\hline
\end{tabular}

Table 2. Infestation index of wheat as a result of Oculimacula spp. fungi, which is the cause of eyespot (\%)

\begin{tabular}{|c|c|c|c|c|}
\hline \multirow{2}{*}{ Vegetation season } & \multirow{2}{*}{ Cultivar } & \multicolumn{2}{|c|}{ Level of agrotechnology } & \multirow{2}{*}{ Seasonal mean } \\
\hline & & A1 (moderate-intensive) & A2 (intensive) & \\
\hline \multirow{2}{*}{$2008 / 2009$} & Komnata & $3.56 a b c^{*}$ & $7.99 \mathrm{bcd}$ & \multirow{2}{*}{$1.41 \mathrm{a}^{* * *}$} \\
\hline & Ostka Strzelecka & $0.00 \mathrm{a}$ & $0.00 \mathrm{a}$ & \\
\hline \multirow{2}{*}{$2009 / 2010$} & Komnata & $17.05 \mathrm{de}$ & $12.45 \mathrm{~cd}$ & \multirow{2}{*}{$20.45 \mathrm{~b}$} \\
\hline & Ostka Strzelecka & $20.98 \mathrm{de}$ & $33.29 \mathrm{e}$ & \\
\hline \multirow{2}{*}{$2010 / 2011$} & Komnata & $0.65 \mathrm{ab}$ & $0.16 \mathrm{a}$ & \multirow{2}{*}{$0.41 \mathrm{a}$} \\
\hline & Ostka Strzelecka & $0.92 \mathrm{ab}$ & $0.16 \mathrm{a}$ & \\
\hline \multicolumn{2}{|c|}{ Mean for level of agrotechnology } & $4.40 \mathrm{a}^{* *}$ & $4.92 \mathrm{a}$ & - \\
\hline
\end{tabular}


Table 3. Wheat yield obtained in the experiment $(\mathrm{t} / \mathrm{ha})$

\begin{tabular}{|c|c|c|c|c|}
\hline \multirow{2}{*}{ Vegetation season } & \multirow{2}{*}{ Cultivar } & \multicolumn{2}{|c|}{ Level of agrotechnology } & \multirow{2}{*}{ Seasonal mean } \\
\hline & & A1 (moderate-intensive) & A2 (intensive) & \\
\hline \multirow{2}{*}{ 2008/2009 } & Komnata & $2.40 \mathrm{~b}^{*}$ & $8.43 \mathrm{~g}$ & \multirow{2}{*}{$7.71 \mathrm{c}^{* * *}$} \\
\hline & Ostka Strzelecka & $9.49 \mathrm{~h}$ & $10.54 \mathrm{i}$ & \\
\hline \multirow{2}{*}{$2009 / 2010$} & Komnata & $1.05 \mathrm{a}$ & $4.29 \mathrm{~d}$ & \multirow{2}{*}{$4.66 \mathrm{a}$} \\
\hline & Ostka Strzelecka & $5.13 \mathrm{e}$ & $8.19 \mathrm{~g}$ & \\
\hline \multirow{2}{*}{ 2010/2011 } & Komnata & $3.46 \mathrm{c}$ & $4.17 \mathrm{~d}$ & \multirow{2}{*}{$5.91 \mathrm{~b}$} \\
\hline & Ostka Strzelecka & $7.61 \mathrm{f}$ & $8.40 \mathrm{~g}$ & \\
\hline \multicolumn{2}{|c|}{ Mean for level of agrotechnology } & $4.86 \mathrm{a}^{* *}$ & $7.33 \mathrm{~b}$ & - \\
\hline
\end{tabular}

Table 4. Weight of 1,000 grains in the experiment (g)

\begin{tabular}{|c|c|c|c|c|}
\hline \multirow{2}{*}{ Vegetation season } & \multirow{2}{*}{ Cultivar } & \multicolumn{2}{|c|}{ Level of agrotechnology } & \multirow{2}{*}{ Seasonal mean } \\
\hline & & A1 (moderate-intensive) & A2 (intensive) & \\
\hline \multirow{2}{*}{$2008 / 2009$} & Komnata & $30.96 a^{*}$ & $58.18 \mathrm{~h}$ & \multirow{2}{*}{$43.99 \mathrm{a}^{* * *}$} \\
\hline & Ostka Strzelecka & $43.11 \mathrm{~cd}$ & 43.70 de & \\
\hline \multirow{2}{*}{ 2009/2010 } & Komnata & $41.23 \mathrm{~b}$ & $58.37 \mathrm{~h}$ & \multirow{2}{*}{$45.64 \mathrm{~b}$} \\
\hline & Ostka Strzelecka & $40.54 \mathrm{~b}$ & $42.41 \mathrm{c}$ & \\
\hline \multirow{2}{*}{ 2010/2011 } & Komnata & $50.32 \mathrm{f}$ & $53.58 \mathrm{~g}$ & \multirow{2}{*}{$48.09 \mathrm{c}$} \\
\hline & Ostka Strzelecka & $44.25 \mathrm{e}$ & $44.21 \mathrm{de}$ & \\
\hline \multicolumn{2}{|c|}{ Mean for level of agrotechnology } & $41.73 \mathrm{a}^{* *}$ & $50.08 \mathrm{~b}$ & - \\
\hline
\end{tabular}

occurrence was only determined by the cultivation season. The infestation index in the season 2009/2010, which was characterized by abundant precipitation, was very high and amounted to $20.45 \%$, on average. In the $2008 / 09$ and 2010/11 seasons, the intensity of the occurrence of fragility may be evaluated as negligible to low. No significant differentiation was noted between the mean index of plant infestation at levels A1 (4.40\%) and A2 (4.92\%). The Komnata cultivar was characterized by a slightly higher infestation index, i.e. $5.22 \%$ (a), on average, in the experiment. In turn, Ostka Strzelecka was a slightly less infested cultivar. The mean in this case was $4.12 \%$ (a). The differences in the infestation index between these cultivars were not statistically significant.

Eyespot is a stem-base disease, which is often observed together with Fusarium foot rot. Such a relationship was demonstrated, inter alia, in the studies by Nieróbca et al. (2008) and Lemańczyk (2012). Wheat plant infestation by fungi of the Oculimacula genus is prompted first of all by high humidity, which was observed by Korbas et al. (2008), Korbas and Mrówczyński (2009), and Budzyński (2012). This information was confirmed in the present study. Weber (2008), Budzyński (2012), and Lemańczyk (2012) emphasized, in turn, that the factor favoring development of crop rotation diseases, i.e. stem-base infections in the case of wheat, is to a high degree improper crop rotation - wheat cultivation after itself or other cereals.

Intensification of the occurrence of stem-base diseases in wheat cultivation determines the amount and quality of the yield obtained. Mean yields and the TGW obtained in this experiment were strongly differentiated and depended on the experimental factors applied (Tables 3, 4). The highest yield was obtained for the Ostka Strzelecka cultivar in the first year of cultivation - at a moderateintensive level it was $9.49 \mathrm{t} / \mathrm{ha}$, while at an intensive level it amounted to $10.54 \mathrm{t} / \mathrm{ha}$. The lowest yield (1.05 t/ha) was noted for Komnata, in the 2009/10 season which was unfavorable to the cultivation. Yields, which, on average, were almost twice as high were obtained at the intensive agrotechnology level when compared to the moderate-intensive level. The 2008/09 vegetation season was the most favorable in terms of yield, as mean yields obtained in this season were significantly the highest. Komnata appeared to be a considerably poorer yielding cultivar (3.97 t/ha) (a) than Ostka Strzelecka. The Ostka Strzelecka yield was over two-fold higher and amounted to $8.23 \mathrm{t} / \mathrm{ha}$ (b). However, the durum wheat cultivar Komnata was characterized by a significantly higher, statistically, TGW compared to the Ostka Strzelecka cultivar of common wheat. In Komnata, the mean TGW was $48.77 \mathrm{~g}$ (b), while in Ostka it was $43.03 \mathrm{~g}$ (a). 
More intensive agrotechnology favored the grain quality obtained. For A1 level, the mean TGW was nearly $42 \mathrm{~g}$, while for A2 level it was slightly above $50 \mathrm{~g}$. The last examination season was the most favorable. The TGW was, on average, slightly over $48 \mathrm{~g}$. The TGW in the 2009/10 season was at an average level, and the finest grain was noted for wheat in the 2008/09 season. The obtained differences in the TGW between particular vegetation seasons were statistically significant.

Budzyński (2012) stressed that wheat yield is affected by a range of factors, but primarily by the atmospheric conditions of the vegetation season (air temperature, sum of precipitation) and agrotechnology (fertilization, plant protection). In turn, Spychaj et al. (2011) emphasized that the technological value of the grain is conditioned not only by environmental conditions and agrotechnological factors, but also by genetic factors, i.e. cultivar features.

When comparing the amount and quality of yield obtained with the intensity of the occurrence of stem-base diseases in the conducted experiment, it may be concluded that seasonal climatic conditions and the agrotechnology level had the highest influence on the yield of both wheat cultivars. Ostka Strzelecka is a cultivar of common wheat. Komnata is a cultivar of durum wheat and it had a lower yield than Ostka Strzelecka, but the obtained Komnata grain (of higher TGW) was of a higher quality. It cannot be concluded that the slightly higher but statistically insignificant susceptibility of durum wheat to stem-base diseases, determined a significant limitation of yield levels, which in this case was characterized by higher quality. Analysis of the results show that mean intensity of the occurrence of both stem-base diseases in experimental seasons does not correlate with the results in the area of the mean levels and quality of the yield.

\section{Conclusions}

Durum wheat of the Komnata cultivar and common wheat of the Ostka Strzelecka cultivar are characterized by a similar susceptibility to the stem-base diseases - Fusarium foot rot and eyespot. The occurrence of Fusarium foot rot in winter durum wheat Komnata and common wheat Ostka Strzelecka cultivation, is strongly dependent on the agrotechnology level applied and the weather conditions of the vegetation season. Intensified symptoms of eyespot were observed on the examined cultivars in seasons with high precipitation levels. An increase in the amount and quality of the obtained grain yield was aided by an intensive technology of cultivation. The durum wheat cultivar was characterized by a lower yield, but a higher TGW. The common wheat cultivar gave a higher yield but a lower grain quality.

\section{References}

Anonymous 2009. Evaluation of measures for the sector of durum wheat in the context of the Common Agricultural Policy - a summary. LMC International. http://ec.europa. eu/agriculture/eval/reports/wheat/syn_sum_pl.pdf [Accessed: January 2013].
Blandino M., Pilati A., Reyneri A. 2009. Effect of foliar treatments to durum wheat on flat leaf senescence, grain yield, quality and deoxynivalenol contamination in North Italy. Field Crops Res. 114 (2): 214-222.

Budzyński W. (ed.). 2012. Pszenice - zwyczajna, orkisz, twarda. Uprawa i zastosowanie. [Wheat - Common, Spelt, Durum. Cultivation and Use]. PWRiL, Poznań, 328 pp.

Champeil A., Doré T., Fourbet J.F. 2004. Fusarium head blight: epidemiological origin of the effects of cultural practices on head blight attacks and the production of mycotoxins by Fusarium in wheat grains. Plant Sci. 166 (6): 1389-1415.

Chekali S., Gargouri S., Paulitz T., Nicol J.M., Rezgui M., Nasraoui B. 2011. Effects of Fusarium culmorum and water stress on durum wheat in Tunisia. Crop Prot. 30 (6): 718-725.

Edwards S.G. 2004. Influence of agricultural practices on fusarium infection of cereals and subsequent contamination of grain by trichothecene mycotoxins. Toxicol. Lett. 153 (1): 29-35.

Fernandez M.R., Chen Y. 2005. Pathogenicity of Fusarium species on different plant parts of spring wheat under controlled conditions. Plant Dis. 89 (2): 164-169.

Ficco D.B.M., Riefolo C., Nicastro G., De Simone V., Di Gesu A.M., Beleggia R., Platani C., Cattivelli L., De Vita P. 2009. Phytate and mineral elements concentration in a collection of Italian durum wheat cultivars. Field Crops Res. 111 (3): 235-242.

Katerji N., Van Hoorn J.W., Hamdy A., Mastrorilli M., Nachit M.M., Oweis T. 2005. Salt tolerance analysis of chickpea, faba bean and durum wheat varieties: II. Durum wheat. Agr. Water Manage. 72 (3): 195-207.

Korbas M., Mrówczyński M. (ed.) 2009. Integrowana produkcja pszenicy ozimej i jarej. [Integrated Production of Winter and Spring Wheat]. Instytut Ochrony Roślin - PIB, Poznań, $168 \mathrm{pp}$.

Korbas M., Mrówczyński M., Paradowski A., HoroszkiewiczJanka J., Jajor E., Pruszyński G. 2008. Ochrona roślin w integrowanej produkcji pszenicy. [Plant protection in integrated production of wheat]. Prog. Plant Prot./Post. Ochr. Roślin 48 (4): 1502-1515.

Lemańczyk G. 2012. Chemiczne zwalczanie chwastów a nasilenie chorób korzeni i podstawy źdźbła zbóż jarych. [Chemical weed control and the severity of root diseases and root rot of spring cereals]. Prog. Plant Prot./Post. Ochr. Roślin 52 (2): 369-376.

Menniti A.M., Maccaferri D.P.M., Casalini L. 2003. Effect of fungicides on Fusarium head blight and deoxynivalenol content in durum wheat grain. Eur. J. Plant Pathol. 109 (2): 109-115.

Nieróbca A., Pudełko R., Kozyra J. 2008. Nasilenie występowania chorób podstawy źdźbła na pszenicy ozimej w zależności od stanowiska w zmianowaniu. [The incidence of stem base diseases on winter wheat depending on the position in the crop rotation]. Prog. Plant Prot./Post. Ochr. Roślin 48 (2): 482-486.

Perkowski J., Stracowiak J., Kiecana I., Golinski P., Chelkowski J. 1997. Natural occurrence of Fusarium mycotoxins in Polish cereals. Cereal Res. Commun. 25 (3/1): 379-380.

Rachoń L. 2004. Ocena przydatności ziarna krajowych i zagranicznych linii i odmian jarej pszenicy twardej (Triticum durum Desf.) do produkcji makaronu. [Assessment of usefulness of domestic and foreign cultivars of spring durum 
wheat (Triticum durum Desf.) for pasta production]. Biuletyn IHAR 231: 129-137.

Rachoń L., Dziamba S., Obuchowski W., Kołodziejczyk P. 2002. Ocena przydatności ziarna odmian pszenicy twardej (Triticum durum) i zwyczajnej (Triticum aestivum ssp. vulgare) do produkcji makaronu. [Evaluation of the usefulness of grain varieties of durum wheat (Triticum durum) and common (Triticum aestivum ssp.vulgare) for the production of pasta]. Ann. UMCS, Sec. E, 57: 77-85.

Rachoń L., Szumiło G. 2006. Plonowanie a opłacalność uprawy pszenicy twardej (Triticum durum Desf.). [Yielding and profitability of hard wheat (Triticum durum Desf.)]. Pam. Puł. 142: 4004-4009.

Rachoń L., Szumiło G. 2009. Yield of winter durum wheat (Triticum durum Desf.) lines in condition of different protection level of plants. Acta Sci. Pol., Agricultura 8 (3): 15-22.

Spychaj R., Gil Z., Chrzanowska-Drożdż B. 2011. Wartość technologiczna ziarna ozimej pszenicy twardej odmiany Komnata $\mathrm{w}$ zależności od sposobu chemicznej ochrony roślin. [The technological value of winter grain durum wheat cultivar Komnata according to how the chemical plant protection]. Biuletyn IHAR 262: 25-38.
Suproniene S., Mankeviciene A., Gaurilcikiene I. 2011. The effects of fungicides on Fusarium spp. and their associated mycotoxins in naturally infected winter wheat grain. Plant Breed. Seed Sci. 64 (4): 123-130.

Vujanovic V., Mavragani D., Hamel Ch. 2012. Fungal communities associated with durum wheat production system: A characterization by growth stage, plant organ and preceding crop. Crop Prot. 37: 26-34.

Wagacha J.M., Muthomi J.W. 2007. Fusarium culmorum: Infection process, mechanisms of mycotoxin production and their role in pathogenesis in wheat. Crop Prot. 26 (7): 877-885.

Weber R. 2008. Występowanie na odmianach pszenicy ozimej kompleksu chorób podstawy źdźbła w zależności od sposobu uprawy i terminu siewu. [Occurrence on varieties of winter wheat root rot complex diseases depending on the method cultivation and sowing date]. Prog. Plant Prot./ Post. Ochr. Roślin 48 (1): 376-380.

Yoshida M., Nakajima T. 2008. Effect of nitrogen application at anthesis on Fusarium head blight and mycotoxin accumulation in breadmaking wheat in the western part of Japan. J. Gen. Plant Pathol. 74 (5): 355-363. 